\title{
The Analysis of Vascular Endothelial Growth Factor Gene Polymorphisms on Clinical and Histopathology Features of Nasopharyngeal Carcinoma
}

\author{
Abdul Qadar Punagi \\ Department of Otorhinolaryngology, Medical Faculty of Hasanuddin University, Makassar, Indonesia
}

\section{Email address:}

qa_dar@yahoo.co.id

\section{To cite this article:}

Abdul Qadar Punagi. The Analysis of Vascular Endothelial Growth Factor Gene Polymorphisms on Clinical and Histopathology Features of Nasopharyngeal Carcinoma. American Journal of Clinical and Experimental Medicine. Vol. 3, No. 4, 2015, pp. 154-161. doi: 10.11648/j.ajcem.20150304.15

\begin{abstract}
Background: Nasopharyngeal malignancy is the first most common malignancy amongst in ear, nose and throat. Incidence rate was 4.7 per 100.000 or $7.000-8.000$ cases per year and most of carcinoma is arising from the epithelial cells. Objective: To analyze the VEGF gene variations at $+405 \mathrm{C} / \mathrm{G}$ and $-460 \mathrm{~T} / \mathrm{C}$ with VEGFR (Flt-4) and LMP-1 tissues expression of nasopharyngeal carcinoma (NPC). Methods: A cross sectional study was carried out with explorative approached at several teaching hospitals in Makassar by Hasanuddin University Research Centre and Eijkman Institute for Molecular Biology on a one-year period, from July 2006 through August 2007. The analysis covered from 90 samples of blood and 45 samples of nasopharynx tissue, consisting of 45 patients for both of the NPC and without NPC as a control. Genomic DNA was extracted from peripheral blood and analyzed by PCR and direct DNA sequencing method for identifying the location of VEGF gene mutation and immunohistochemical expression of VEGFR (Flt-4) and LMP-1 were performed in 45 NPC biopsy samples with avidin-biotin method. Results: The frequencies of $+405 \mathrm{C} / \mathrm{G}$ and $-460 \mathrm{~T} / \mathrm{C}$ were about $50 \%$, with higher in $+405 \mathrm{C} / \mathrm{G}$ (hot spot), mostly genotype variant was heterozygote (CG). Our results confirmed that untranslated and promoter region of VEGF gene were higher polymorphic. GC and CC haplotype at $+405 \mathrm{C} / \mathrm{G}$ and $-460 \mathrm{~T} / \mathrm{C}$ of VEGF gene more susceptible to NPC compared with CT haplotype but no statistical significant. Conclusion: There were no relationships between genotype distribution and allele frequencies at VEGF gene $+405 \mathrm{C} / \mathrm{G},-460 \mathrm{~T} / \mathrm{C}$ and $-457 \mathrm{~T} / \mathrm{C}$ with the NPC risk factors.
\end{abstract}

Keywords: Nasopharyngeal Carcinoma (NPC), Vascular Endothelial Growth Factor (VEGF), Latent Membrane Protein (LMP-1)

\section{Introduction}

The highest incidence of nasopharyngeal malignancy is in Guang Dong Province, China, which are 40-50 cases per 100.000 populations per year. Then it is followed by, Eskimo, Tunisia, Philippines, Malaysia, Algeria and Indonesia. It is rare in whites, Japan, and India. From nasopharyngeal carcinoma profile data report in Hasanuddin University teaching hospital, Makassar from January 2000 to June 2007, it was reported that nasopharyngeal carcinoma (NPOC) accounts $33 \%$ of all malignancy in ear, nose, and throat with highest incidence in 4 and 5 decades age groups, male and female proportion; 2-3:1, and most of the histopathology type is anaplastic carcinoma, with the high tendency of metastasis. $1,2,3$ NPC is often undetected in the early stage because the variations of symptoms and difficulty of examining the nasopharynx; therefore, the mortality rate is high, which the patients seek medical care in stage III or IV with 10 years survival rate about $10 \%$. $^{4,5}$

One of the NPC treatments is radiotherapy, which is the main modality; chemotherapy and resection depend on the stage and each hospital protocol. With the low survival rate, patients with late stadium often treated with chemotherapy adjuvant, concomitant, or neo adjuvant with radiotherapy of sandwich fashion, but the result is not satisfying. ${ }^{6-10}$

One of the risk factor for somatic cell malignancy process is gene mutation. Gene mutation can be caused by viral infection, radiation, and carcinogenic substance. Epstein Barr virus (EBV) is a Herpesviridae family, with gamma Herpes virus subfamily, genera lymphocryptovirus. EBV could be detected with serology test, cell culture, and DNA technology. There are two types of EBV, type 1 and 2. Both 
of this type could be found in most of human oropharynx. EBV type 1 is more often found in industrial countries, and type 2 is more often found in Africa and developing countries. $^{11,12,13}$

Latent Membrane Protein (LMP-1) product is a integral membrane protein (onkoprotein), was found in $95.6 \%$ of NPC patients. ${ }^{14}$ EBV LMP-1 induce COX-2 (cyclooxygenase) expresion from NFkB through CTAR1 and CTAR2 (carboxyl terminal activation region) in nasopharyngeal epitelial cells, induce prostaglandine $E_{2}$ expresion and increase the production of vascular endothelial growth factor (VEGF), which have a role in NPC angiogenesis.

Certain polmorphisms have been reported in VEGF genes $(+405 \mathrm{C} / \mathrm{G}$ and $-460 \mathrm{~T} / \mathrm{C})$ in lung cancer, that is linked to VEGF protein variations. ${ }^{15,16}$ Knowing the VEGF gene DNA sequences, it is expected to know about the individual clinical manifestation of NPC. There is a meaningful relationship between VEGF gene variations on $+405 \mathrm{C} / \mathrm{G}$ and $-460 \mathrm{~T} / \mathrm{C}$ alleles in squamous cell cancer ${ }^{15,16,17}$; therefore in this study, we want to assess the VEGF gene variations on $+405 \mathrm{C} / \mathrm{G}$ and $-460 \mathrm{~T} / \mathrm{C}$ alleles with stages, histopathology of NPC with different ethnic groups, and if there is a new genetic variation in the NPC patients in Makassar.

\section{Methods}

This study was a cross-sectional study with explorative approach and case-control by analytic. This study conducted in Teaching hospitals in Makassar, from July 2006 to August 2007. The samples were NPC patients who seek care in the teaching hospitals, and met the inclusion criteria, and were taken using non-random sampling. Amount of the cases were 45 and controls were 45.

Staining procedure was the $5 \mu \mathrm{m}$ thick paraffin block, placed under pre cleaned white glass with poly L lysine coated, then incubated for one night. After the samples were deparaffinized, it is washed using Phosphat Buffer Saline (PBS) and citric buffer, then blocking normal serum (Ultra $V$ Block) was added. Then, primary anti LMP-1 antibody (Novo Costra) and anti VEGF-R(Flt-4) (Lab. Viscon) were added, and stored in refrigerator for 24 hours. Next, the samples were washed by PBS, and were added secondary antibody (Biotinylated Goat Anti Polyvalent), incubated, were washed using PBS, and were added streptavidin peroxidase, and incubated in room temperature. Next, it is washed again using PBS, were added DAB (Diamino benzidine), and were washed using $\mathrm{H}_{2} \mathrm{O}$, and stained using hematoxillin-eosin. LMP-1 positive expression is seen as brownish granules in membrane and cytoplasm, and VEGF-R is seen as brownish granules in cell cytoplasm. The expression count was done under binoculary microscope with 100-200 times magnification and was choosen randomly and counted in 100-200 cells.

\section{Interpretation}

LMP-1 (semi quantitative)
0 : negative, $+1:$ weak $(<10 \%$ expression)

$+2:$ moderate $(10 \%-25 \%)+3:$ strong (expression $>25 \%)$

VEGF- R (Flt-4) (semi quantitative)

0 : negative, $+1:<25 \%$ expression

$+2: 26 \%-50 \%$ expression $+3: 51 \%-75 \%$ expression

$+4:>75 \%$ expression

VEGF DNA extraction was using Chelex method, VEGF

DNA amplication:

Primer :

Forward : $-460 \mathrm{~F}=5$ ' - CCT CTT TAG CCA GAG CCG GGG -3'

$+405 \mathrm{~F}=5$ ' - CGA CGG CTT GGG GAG ATT GC-3'

Reverse : $-460 \mathrm{R}=5$ '- TGG CCT TCT CCC CGC TCC GAC-3'

$+405 \mathrm{R}=5$ ' - GGG CGG TGT CTG TCT GTC TG-3'

After the PCR process, the samples were visualized under UV light. In the sequencing, PCR products were placed in ABI-prism, and compared with human VEGF gene database. Univariate analysis for categories data with nominal and ordinal scales, were using Chi square test likelihood, Chi square test Spearman and Odds Ratio (OR). Bivariate analysis was using Spearman correlation.

\section{Results}

In July 2006 to August 2007 period, it has been done, a research for VEGF gene polymorphism in NPC based on genotype distribution and its haplotype on $+405 \mathrm{C} / \mathrm{G}$, untranslated part and $-460 \mathrm{~T} / \mathrm{C}$ which is VEGF gene promoter in NPC.

On 90 samples, which was consisted of 45 NPC cases and 45 healthy controls. Immunohistochemistry test was done for evaluating VEGFR and LMP-1 expression in cases only, because the control group was not undergone biopsy evaluation. We did not evaluate RFLP (Retriction Fragment Length Polymorphism) because enzyme restriction; BsaH I and BsmFI could not be obtained commercially. So, We did direct sequencing from $3 \mathrm{ml}$ Cubiti vein blood sample on all samples.

\subsection{Sample Characteristics}

From the sample characterictics, we found the NPC patients age mean is $45.80 \pm 13.70$ year old. Male are 38 $(84.44 \%)$ and female were 7 (15.56\%). There are two ethnics in our study, Buginese consisted of 21 patients $(46.67 \%)$ and Makassarese consisted 12 (26.67\%). From the control group, the age mean is $39.22 \pm 12.53$ years.

Primary complaint from NPC patients were bloodstained discharge or epistaxis are $16(35.56 \%)$ followed by 9 cephalgia (20\%). The chief complaint was neck mass 24 $(53.33 \%)$ and nasal obstruction 10 (22.22\%). In early stage, we found untypical symptoms, such as unilateral hearing loss, tinnitus, and aural fullness.

\subsection{PCR Result}

We did PCR test, and succeed amplifing DNA target with 
280 bp, with VEGF gene mutation on allele $+405 \mathrm{C} / \mathrm{G}$ inside (Figure 1.)

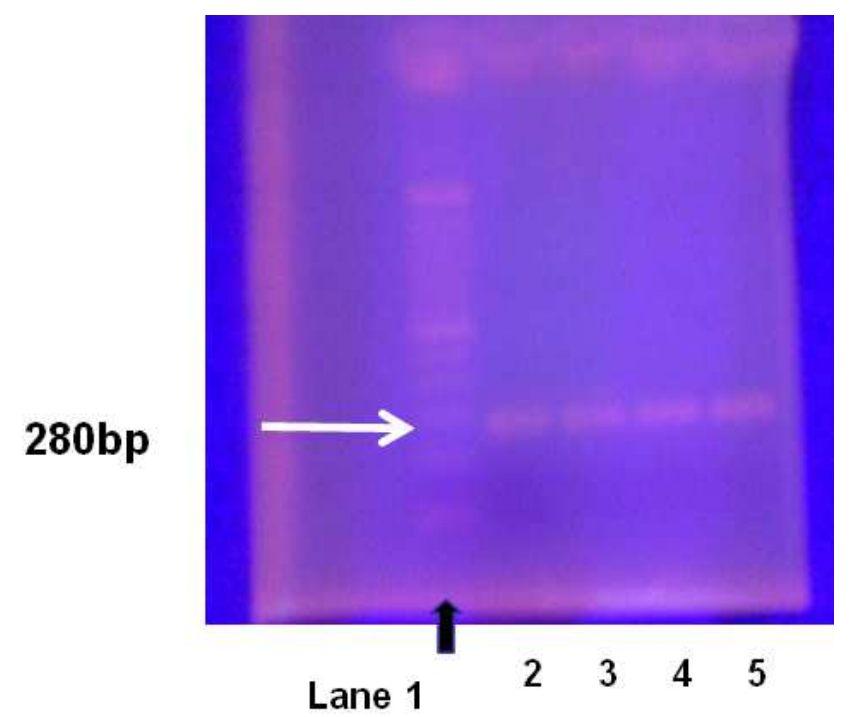

Figure 1. DNA VEGF allele +405 C/G PCR Product Electrophoresis. Lane 1 : marker 2,3,4 and 5 represents sample with $280 \mathrm{bp}$.

Then, DNA target amplified with $200 \mathrm{bp}$, with VEGF gene mutation on allele $-460 \mathrm{~T} / \mathrm{C}$ inside (Figure 2. )

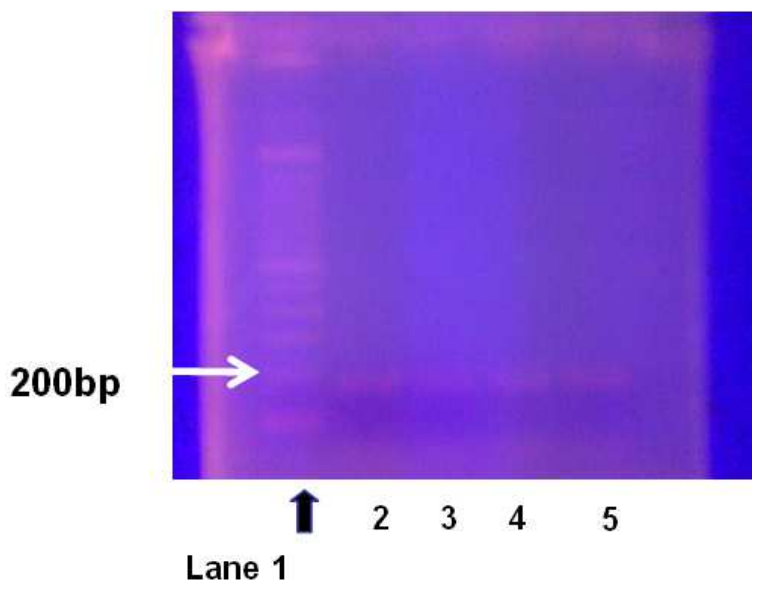

Figure 2. DNA VEGF allele -460 T/C PCR Product Electrophoresis. Lane 1 marker 2,3,4 and 5 represents sample with $280 \mathrm{bp}$.

\subsection{NPC Stage Characteristics}

Based on TNM-UICC 2002, we found stage III: 19 (42.22\%), next stage IV (IVA, IVB dan IVC): 14 (31.11\%) and stage IIB 8 (17.78\%).

\subsection{NPC Histopathology Characteristics}

Based on WHO 1979, we found WHO type II: 15 (33.33\%) and WHO type III: $30(66.67 \%)$ and no WHO type I.

\subsection{Risk Factor}

The risk factor in case group was found that the preserved foods, like salted fish, canned food, and smoked meat were up to $95.56 \%$, burned woods and mosquito repellent were up to $82.22 \%$, smoking was $42.22 \%$, alcohol $33.33 \%$, betel chewere $6.67 \%$, Buginese-Makassarese 32 (71.11\%) and others were 13 (28.89\%).

The risk factor in control group was found that the preserved foods, like salted fish, canned food, and smoked meat were up to $88.89 \%$, burned woods and mosquito repellent were up to $55.56 \%$, smoking was $51.11 \%$, alcohol $28.89 \%$, betel chewere $11.11 \%$, Buginese-Makassarese 27 $(60.00 \%)$ and others were $18(40.00 \%)$.

\subsection{LMP-1 and VEGF-R (Flt-4) Expression}

Immunochemistry tests using avidin-biotin method techniques were done in 45 NPC cases biopsy tissues.

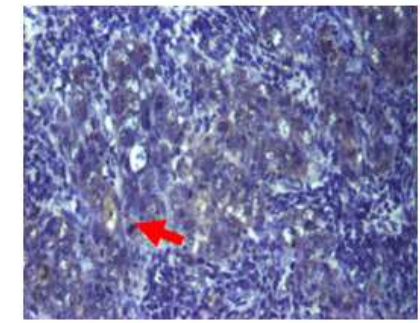

LMP $1.200 x, 2+$, WHOII, St II B (N0.44)

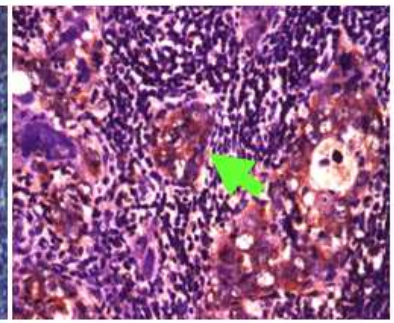

VEGF-R (Flt-4), 200x, 4+, WHOII, St II B (N0.44)
A

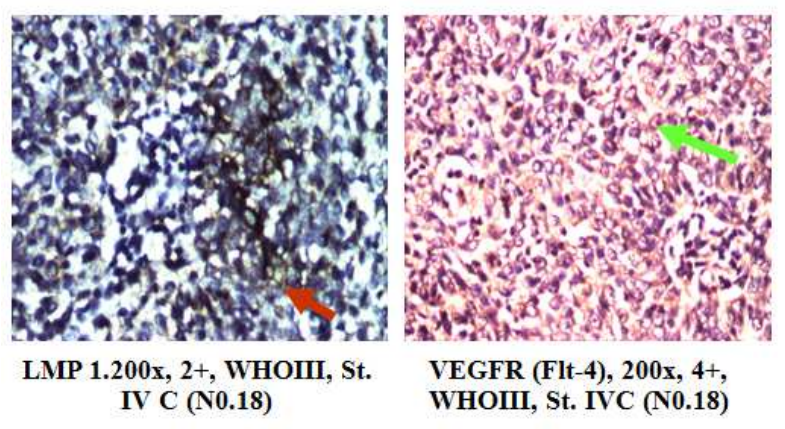

B

Figure 3. LMP-1 and VEGF-R (Flt-4) Expression (Immunochemistry) WHO Type III and Stage IV C (A). LMP-1 and VEGF-R (Flt-4) Expression (Immunochemistry) WHO Type II and Stage II B (B).

Positive expression of LMP-1 in nasopharyngeal biopsy tissue seems like brownish granula in membran and cytoplasm, while in VEGF-R(Flt-4) seems like brownish granula in cell cytoplasm (Figure.3). From primary data, we found LMP-1 expresion was 42.1\%, and VEGF-R (Flt.4) $100 \%$, there was LMP-1 overexpression $(\geq+2)$ as many as 13 (28.89\%) dan VEGF-R (Flt-4) 19 (42.22\%).

Spearman correlation statistical test for VEGF-R(Flt-4) and LMP-1 expressions role against NPC symptomps, consist of stage based on TNM-UICC 2002 and histopathology characteristic based on WHO 1979, shows no significant correlation between stages and VEGF-R (Flt-4) (0.251) and LMP-1 (0.257) expressions, that means higher VEGF-R (Flt4) and LMP-1 expression in early stage. There is significant inverted correlation between histopathology characteristic 
and VEGF-R (Flt-4) $(\mathrm{r}=-0.426, \mathrm{p}=0.002)$ and LMP-1 $(\mathrm{r}=-$ 467, $\mathrm{p}=0.001$ ) expressions, means VEGF-R (Flt-4) and LMP-1 expressions are higher in WHO type II (well differentiated) then WHO type III (poorly differentiated). There is strong correlation $(r=0.990, p=0.000)$ and statistically significant between LMP-1 and VEGF-R (Flt-4) expression. There is no significant correlation (Spearman) $(p>0.05)$ between symptoms, consist of stage and histopathology, LMP-1 and VEGF-R (Flt-4) expressions with alcohol, smoking, betel chewer, pollutants, and preserved foods.

\subsection{VEGF Gene Genotype Distribution}

CG $(p=0.524$, OR $=-)$ and $\mathrm{GG}(p=0.467$, OR $=-)$ Genotype within VEGF gene $+405 \mathrm{C} / \mathrm{G}$ is not found as risk factor for NPC incidents. While, Allele C (OR : 0.859) against NPC incidents is not statistically significant $(\mathrm{p}=$ 0.696). Non - CC genotype within VEGF gene $+405 \mathrm{C} / \mathrm{G}$ is not found as NPC risk factor.
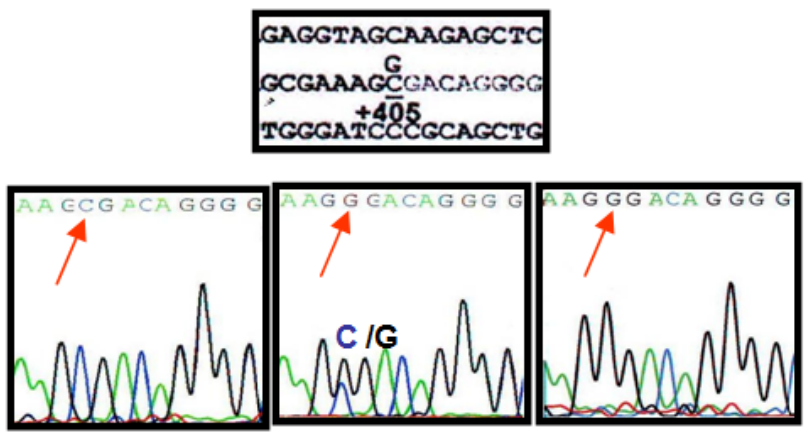

A

B

C

Figure 4. DNA Sequencing Electroferogram from VEGF allele $+405 \mathrm{C} / \mathrm{G}$ with interchanging base from cytosine $(C)$ to guanine $(G)$. A = Wild type, $B=$ Heterozygote and $C=$ homozygote

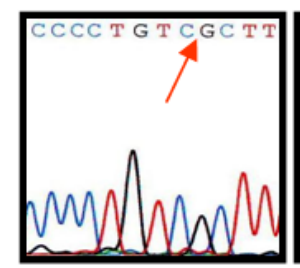

A

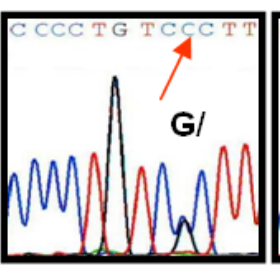

B

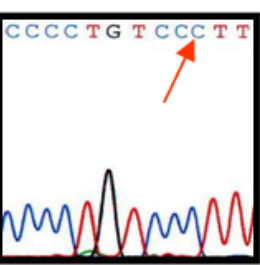

C
Figure 5. DNA Sequencing Electroferogram from VEGF allele $+405 \mathrm{C} / \mathrm{G}$ (reverse sequence) with interchanging base from cytosine $(C)$ to guanine $(G)$ $A=$ Wild type, $B=$ Heterozygote and $C=$ homozygote

$-460 \mathrm{~T} / \mathrm{C}$ VEGF genes, TC genotype $(\mathrm{p}=0.548, \mathrm{OR}=$ $0.696 ; 0.213-2.276 ; 95 \% \mathrm{CI})$ and $\mathrm{CC}(\mathrm{p}=0.581 ; \mathrm{OR}=$ $0.648 ; 0.139-3.036 ; 95 \% \mathrm{CI})$ were not found as risk factor, and so as T allele ( $\mathrm{p}=0.599$; OR : $0.809 ; 0.367-1.785 ; 95 \%$ $\mathrm{CI}$ ), was not statistically significant and the $-460 \mathrm{~T} / \mathrm{C}$ VEGF gene Non TT genotype was not found as NPC risk factor.
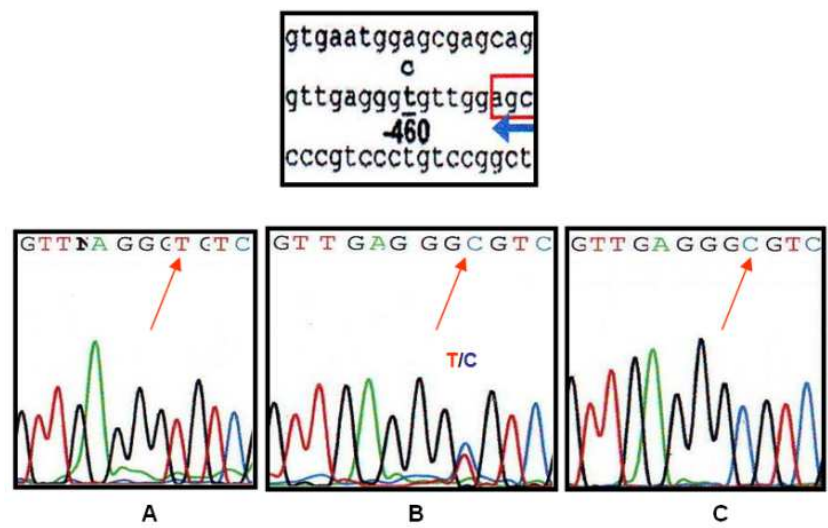

Figure 6. DNA Sequencing Electroferogram from VEGF allele $-460 \mathrm{~T} / \mathrm{C}$ with interchanging base from timine $(T)$ to cytosine $(C)$.. A= Wild type, $B=$ Heterozygote and $C=$ homozygote.

Genetic variation of $-457 \mathrm{~T} / \mathrm{C}$ is a new variant in VEGF gene in NPC, and no one has ever reported it. CC genotype is more than TC genotype, risk estimation could not defined because there was no electroferogram of TT genotype (wild type) .

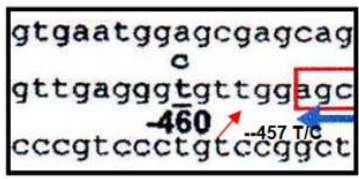

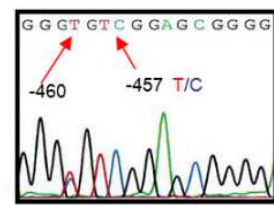

A

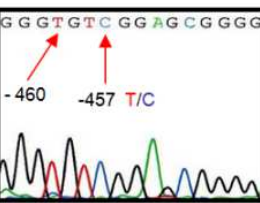

B

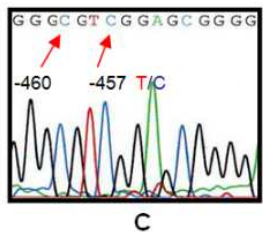

Figure 7. DNA Sequencing Electroferogram from VEGF allele $V$ with interchanging base from timine (T) to cytosine (C).. A= Wild type, $B=$ Heterozygote and $C=$ homozygote

\subsection{VEGF Gene $+405 C / G$ and $-460 T / C$ Haplotypes}

There were no GC, CC, GT, and CT haplotypes distribution difference in cases and controls group. $+405 \mathrm{C} / \mathrm{G}$ and $-460 \mathrm{~T} / \mathrm{C}$ GC haplotypes have a risk 1.24 times higher to suffer NPC, but it is statistically insignificant. $+405 \mathrm{C} / \mathrm{G}$ and $-460 \mathrm{~T} / \mathrm{C}$ haplotypes have 3.21 times higher to suffer NPC than $\mathrm{CT}$, but statistically insignificant. Meanwhile, $+405 \mathrm{C} / \mathrm{G}$ and $-460 \mathrm{~T} / \mathrm{C}$ GT haplotypes could not be proved as risk factor to suffer NPC and statistically insignificant.

\subsection{Genotypes Distribution, Allele Frequencies, and VEGF Gene Haplotypes Relationship with Clinical Symptoms (Stages and Histopathology), Expressions (VEGF-R (Flt-4) and LMP-1) and Risk Factors}

\subsubsection{Mutant Variant with Stages}

It could not be proved about genotypes and allele frequencies of VEGF genes $+405 \mathrm{C} / \mathrm{G}(\mathrm{p}=0.815, \mathrm{p}=0.923)$, $460 \mathrm{~T} / \mathrm{C}(\mathrm{p}=0.548-0.599)$ and $-457 \mathrm{~T} / \mathrm{C}(\mathrm{p}=0.237, \mathrm{p}=0.269)$ relationship against NPC stages. G allele frequency was 
higher than $\mathrm{C}$ allele in $+405 \mathrm{C} / \mathrm{G}$ and $\mathrm{C}$ allele was higher than $\mathrm{T}$ allele in $-457 \mathrm{~T} / \mathrm{C}$, while $\mathrm{T}$ allele was higher than $\mathrm{C}$ allele in $-460 \mathrm{~T} / \mathrm{C}$ against NPC early stages (I-IIA) and late stages (IIB-IVC), but it is statistically insignificant.

\subsubsection{Mutant Variant with Histopathology Characteristics}

It could not be proved about genotypes and allele frequencies of VEGF genes $+405 \mathrm{C} / \mathrm{G}(\mathrm{p}=0.854, \mathrm{p}=0.924)$, $460 \mathrm{~T} / \mathrm{C}(\mathrm{p}=0.509, \mathrm{p}=0.684)$ and $-457 \mathrm{~T} / \mathrm{C}(\mathrm{p}=0.237, \mathrm{p}=$ 0.268) relationship against NPC histopathology characteristics. $\mathrm{G}$ allele frequency was higher than $\mathrm{C}$ allele in $+405 \mathrm{C} / \mathrm{G}$, and $\mathrm{C}$ allele was higher than $\mathrm{T}$ allele in $-460 \mathrm{~T} / \mathrm{C}$ and $-457 \mathrm{~T} / \mathrm{C}$ against histopathology characteristic WHO II, but statistically insignificant. $\mathrm{G}$ allele frequency was higher than $\mathrm{C}$ allele in $+405 \mathrm{C} / \mathrm{G}$ in WHO II and III. C allele was higher than $\mathrm{T}$ allele in $-460 \mathrm{~T} / \mathrm{C}$ in WHO II, but was lower in WHO III. C allele -457 T/C frequency was higher in WHO II and III, but statistically insignificant.

\subsubsection{Mutant Variant with LMP-1 and VEGF-R (Flt-4) Expressions}

It could not be proved about genotypes and allele frequencies of VEGF genes $+405 \mathrm{C} / \mathrm{G}(\mathrm{p}=0.927, \mathrm{p}=0.969)$, $460 \mathrm{~T} / \mathrm{C}(\mathrm{p}=0.532, \mathrm{p}=0.978)$ and $-457 \mathrm{~T} / \mathrm{C}(\mathrm{p}=0.579, \mathrm{p}=$ 0.623 ) relationship against VEGF-R (Flt-4) expressions in NPC. G allele frequency was higher than $\mathrm{C}$ allele in +405 $\mathrm{C} / \mathrm{G}$, while $\mathrm{C}$ allele was higher than $\mathrm{T}$ allele in $-457 \mathrm{~T} / \mathrm{C}$, and $\mathrm{T}$ allele was higher than $\mathrm{C}$ allele in $-460 \mathrm{~T} / \mathrm{C}$ and $\mathrm{T}$ allele frequency was higher than $\mathrm{C}$ allele in $-460 \mathrm{~T} / \mathrm{C}$ against VEGF gene VEGF-R(Flt-4) expression, but statistically insignificant.

It could not be proved about genotypes and allele frequencies of VEGF genes $+405 \mathrm{C} / \mathrm{G}(\mathrm{p}=0.984, \mathrm{p}=0.980)$, $460 \mathrm{~T} / \mathrm{C}(\mathrm{p}=0.698, \mathrm{p}=0.893)$ and $-457 \mathrm{~T} / \mathrm{C}(\mathrm{p}=0.827, \mathrm{p}=$ 0.839 ) relationship against VEGF gene LMP-1 expressions in NPC. G allele frequency was higher than $\mathrm{C}$ allele in +405 $\mathrm{C} / \mathrm{G}$, and $\mathrm{C}$ allele was higher than $\mathrm{T}$ allele in $-457 \mathrm{~T} / \mathrm{C}$, and $\mathrm{C}$ allele frequency was equal with $\mathrm{T}$ allele in $-460 \mathrm{~T} / \mathrm{C}$ against LMP-1 expression, but it is statistically insignificant.

\subsubsection{Mutant Variant with Risk Factors}

Statistically significant relation could not be proved about genotypes and allele frequencies of VEGF genes $+405 \mathrm{C} / \mathrm{G}$ and $-457 \mathrm{~T} / \mathrm{C}$ against betel, pollutants, preserved foods, and ethnic group. But there was statistically significant relation between genotype and allele frequency in $-460 \mathrm{~T} / \mathrm{C}$ against alcohol consumption $(\mathrm{p}=0.070)$ and smoking $(\mathrm{p}=0.041)$.

Smoking patients with TC genotype variation in VEGF gene $-460 \mathrm{~T} / \mathrm{C}$ is 4.3 times higher risk to suffer NPC, and statistically significant $(p=0.034)$. Smoking habit with $C C$ genotype in VEGF gene $-460 \mathrm{~T} / \mathrm{C}$ is 7.6 times higher risk to suffer NPC, and statistically significant $(p=0.040)$. Alcohol drinker with TC genotype in VEGF gene $-460 \mathrm{~T} / \mathrm{C}$ is 5.6 times higher risk to suffer NPC, and statistically significant $(p=0.025)$. Alcohol drinker with CC genotype in VEGF gene $-460 \mathrm{~T} / \mathrm{C}$ is 2.6 times higher risk to suffer NPC, and statistically significant $(p=0.370)$.

\section{Discussion}

This research was conducted in the form of analyzing VEGF gene polymorphism, including genotypes, allele frequencies, and $+405 \mathrm{C} / \mathrm{G}$ and $-460 \mathrm{~T} / \mathrm{C}$ haplotypes against clinical symptomps and histopathology in NPC.

From the sample characteristics, Buginese and Makassarese ethnic groups is the most group suffering NPC in Makassar $32(71.11 \%)$, similarly to a study conducted in Makassar in $1997 .^{5}$ But it does not represent actual characteristic because Chinese ethnic group was not represented in this study, which is the highest incidence in the world. ${ }^{18}$ The age group mean is $45.80 \pm 13.70$, means it was in productive age. Male are $38(84.44 \%)$ dan female were $7(15.56 \%)$, with ratio $5: 1$, is higher than the previous study which is 2-3: 1 and it is probably caused by the smaller samples than before. ${ }^{4,} 8,14$ Primary complaint in NPC patient in this study was epistaxis with 16 patients $(35.56 \%)$, then cephalgia were 9 patients $(20 \%)$. The most chief complaint is superolateral neck mass by 24 patients $(53.33 \%)$, then nasal obstruction with 10 patients $(22.22 \%)$, and there are untypical symptomps, like tinnitus, aural fullness, unilateral hearing loss in the early stages; different with the past study, there are only two primary complaint, the neck mass and nasal obstruction. ${ }^{5,19}$ It means flu like symptomps with bloodstained discharge and chronic cephalgia, tinnitus or unilateral conductive hearing loss must be suspected as a malignancy until is proven not a malignancy from complete ENT examination. Chief complaints in this study are the same from past study, that are neck mass and nasal obstruction. It means, there is no changing from patients awareness to have an early ENT examination or misdiagnosed in the primary health care.

Based on TNM-UICC 2002 stages, stage III 19 (42.22\%) then stage IV (IVA, IVB and IVC) 14 (31.11\%) and stage IIB $8(17.78 \%)$, there are no difference from the past study. ${ }^{4,5,6}$, 17 Based on WHO 1979 histopathology, WHO type III 30 (66.67\%), type II $15(33.33 \%)$ and no WHO type I, same as the report that by Fransisca and Perkasa, but it is different from Xie K. that even WHO type III is the most, they found WHO type I in North America up to $25 \%$, in South China is $2 \% .{ }^{19,20,21}$ Khabir et al. reported the WHO type I as many as $1.2 \%$ in North Africa, with WHO type II and III nearly $100 \%$, that WHO type III is $100 \%$ correlated with EBV infection. ${ }^{18,22,23}$ It means, the NPC incidence in Makassar is well correlated with EBV infection. Thus, diagnostic, prognostic, and therapeutic efforts are focused to molecular biology approach against EBV.

In this study, VEGF-R (Flt-4) and LMP-1 expressions from biopsy tissues with immunochemistry test with avidin biotin method technique is found positive expression of LMP-1 in nasopharyngeal biopsy tissue seems like brownish granula in membran and cytoplasm, while in VEGF-R (Flt-4) seems like brownish granula in cell cytoplasm. We found LMP-1 expresion was $42.1 \%$, lower from the study by Khabir A et al. with $60 \%$ and VEGF-R (Flt.4) 100\%, same with the result by Soo R et al. and higher from Liu XF et al. 
that is $61.25 \% .^{17,24,25}$ From LMP-1 overexpression $(\geq+2)$ as many as 13 (28.89\%) dan VEGF-R (Flt-4) are 19 (42.22\%), it means not all the NPC express LMP-1, even in EBV infected epithelial cell and actively replicating. ${ }^{26}$ Based on that statement, it is needed to find another oncoproteins alternative as a biomarker beside LMP-1, for more accute diagnostic and prognostic consideration.

VEGF-R (Flt-4) is a receptor from VEGF-C and very important in angiogenesis and lymphangiogenesis, it means there is a regional metastatic potential to lymph nodes is high. This can explain that neck mass is still the chief complaint in NPC patients in Makassar.

Spearman correlation statistical test result for VEGF-R (Flt-4) and LMP-1 expressions role against NPC symptomps, consist of stage based on TNM-UICC 2002 and histopathology characteristic based on WHO 1979, shows no significant correlation $(\mathrm{p}>0.05)$ between stages and VEGF-R (Flt-4) (0.257) and LMP-1 (0.251) expressions, that means, higher VEGF-R (Flt-4) and LMP-1 are expressed in early stage. It means VEGF-R (Flt-4) and LMP-1 probably has a role in early stage NPC carcinogenesis, similiar to $\mathrm{Bcl}-2$ (Homolog) role in Colorectal carcinoma. ${ }^{27}$

There is no significant correlation between symptoms, consists of stage and histopathology, LMP-1 and VEGF-R (Flt-4) expressions, with alcohol, smoking, betel chewer, pollutants, and preserved foods in NPC. There is a strong correlation between LMP-1 and VEGF-R (Flt-4) expression in NPC, it means the higher LMP-1 expression and VEGF-R (Flt-4) expression is higher too. Thus, LMP-1 is a important regulator (Up-regulator) of VEGF-R (Flt-4) and has a angiogenic potential as a pleiotropic character from LMP-1 beside from transcription activation, gene expression, and cell transformation, cell growth and death. ${ }^{13,28}$

Sequence variation from VEGF gene could affect VEGF production and activity that causing susceptibillity difference between individuals against various of disease like lung carcinoma (squamous cell carcinoma), but from this study in $\mathrm{NPC}$, we found $\mathrm{CG}, \mathrm{GG}$ and $\mathrm{C}$ allele in VEGF gene +460 $\mathrm{C} / \mathrm{G}$, it could not prove as a risk factor for NPC incidence in Makassar. Furthermore, new mutant variation in $-457 \mathrm{~T} / \mathrm{C}$ that have not been reported before with TC, CC genotypes and $\mathrm{T}$ allele could not be proven as a risk factor for NPC in Makassar. It caused by there was no electroferogram result of TT genotype as a base of wild-type homozygot allele, and complicates the evaluation of genotype distribution and allele frequency.

Non-CC genotype VEGF gene $+405 \mathrm{C} / \mathrm{G}$, which in the case of $94.44 \%, 97.14 \%$ controls $(\mathrm{OR}=0.971 ; 95 \% \mathrm{CI} ; 0.58$ to 16.163$)$ and non-TT genotype $-460 \mathrm{~T} / \mathrm{C}$ in the case of $78.12 \%, 70.97 \%$ controls $(\mathrm{OR}=0.684 ; 95 \% \mathrm{CI} ; 0.218$ to 2.144) has not been proven as risk factors of NPC in Makassar. The frequency of non $\mathrm{CC}+405 \mathrm{C} / \mathrm{G}$ and non $-\mathrm{TT}$ $460 \mathrm{~T} / \mathrm{C}$ equal those found by Lee $\mathrm{S}$. J. in squamous cell carcinoma of the lung. ${ }^{13}$ This means that non-CC and non-TT which is a form of polymorphism $+405 \mathrm{C} / \mathrm{G}$ and $-460 \mathrm{~T} / \mathrm{C}$ (frequency of more than 1\%), as reported by Steven $\mathrm{A}$ et al. found as much as $67.50 \%$ in breast and endometrial cells in the UK, Prats AC et al. found $40 \%$ of the population of diabetic retinopathy in Japanese, while Lee SJ et al. found in lung squamous cell carcinoma of $55.70 \%$ in Korea. ${ }^{15,} 16,29$ Therefore, highly polymorphic VEGF gene especially at positions $+405 \mathrm{C} / \mathrm{G}$ and $-460 \mathrm{~T} / \mathrm{C}$ as well as the $-457 \mathrm{~T} / \mathrm{C}$ which is a variant of a new mutation that has not been previously reported. It is also no reports of VEGF gene allele polymorphism $+405 \mathrm{C} / \mathrm{G}$ and $-460 \mathrm{~T} / \mathrm{C}$ on the NPC until we made this study.

Haplotype GC and CC at VEGF gene $+405 \mathrm{C} / \mathrm{G}$ and -460 $\mathrm{T} / \mathrm{C}$ at risk of suffering from NPC compared to $\mathrm{CT}$, although it is not statistically significant, while the GT haplotype at VEGF gene $+405 \mathrm{C} / \mathrm{G}$ and $-460 \mathrm{~T} / \mathrm{C}$ at risk NPC suffer than CT but was not statistically significant. Compared to the results of the studies on breast cells, endometrial and lung squamous cell carcinoma before, is seen a higher frequency of mutations in the variant allele $+405 \mathrm{C} / \mathrm{G}$ than $-460 \mathrm{~T} / \mathrm{C}$, as obtained in this study. This means that the allele $+405 \mathrm{C} / \mathrm{G}$ is a hot spot of VEGF gene. This explains the genetic variants of VEGF are a form of VEGF gene polymorphisms in the promoter region of high. ${ }^{16}$

In the NPC early stage (I - IIA) or advanced (IIB - IVC) turns the $\mathrm{G}$ allele frequency was higher than the $\mathrm{C}$ allele at $+405 \mathrm{C} / \mathrm{G}$, allele $\mathrm{C}$ higher than $\mathrm{T}$ at $-457 \mathrm{~T} / \mathrm{C}$ and $\mathrm{T}$ alleles more higher than the $\mathrm{C}$ allele at VEGF gene $-460 \mathrm{~T} / \mathrm{C}$ in NPC patients in Makassar, although it is not statistically significant. So the $\mathrm{G}$ allele has a role in the early and advanced stages of NPC, although it is not statistically significant, but still requires further study with a larger sample size.

There were no relationships between genotype distribution and allele frequencies at VEGF gene $+405 \mathrm{C} / \mathrm{G},-460 \mathrm{~T} / \mathrm{C}$ and $-457 \mathrm{~T} / \mathrm{C}$ with the NPC risk factors in Makassar, except in person with a variety of TC and CC genotypes VEGF gene $460 \mathrm{~T} / \mathrm{C}$ with smoking habit 4.3 and 7.6 times likely to suffer from NPC earlier than nonsmokers, and it is statistically significant. Person with $\mathrm{TC}$ and $\mathrm{CC}$ genotypes variation VEGF gene $-460 \mathrm{~T} / \mathrm{C}$ with alcohol drinking habits of 5.6 and 2.6 times likely to suffer from NPC than non drinking alcohol. From the viewed of genotype TC, CC and allele T at $-460 \mathrm{~T} / \mathrm{C}$ without smoking or alcohol compared to those with the habit of smoking or drinking alcohol on the risk of suffering from NPC, it was obvious the interaction of genetic and environmental on the incidence of NPC. That is phenotypically expression of VEGF gene in the $-460 \mathrm{~T} / \mathrm{C}$ on the NPC is influenced by environmental factors.

Nasopharyngeal carcinoma is still the most common malignancy in head and neck in Indonesia. Buginese and Makassarese ethnic groups are still the most group suffering NPC in Makassar with primary complaint and most of the chief complaint is superolateral neck mass, which caused by VEGF-R(Flt-4) overexpression, which is a receptor from VEGF-C, that is an important in angiogenesis and lymphangiogenesis; therefore, has a high potential to regional metastatic of lymphnodes, nasal obstruction, and untypical symptomps, like tinnitus, aural fullness, and unilateral hearing loss in earlier stage, which can be misdiagnosed in the primary healthcare. We found most of them seek 
healtcare in stage III, that has lower survival rates and poor prognosis. Means, we need to achieve preventive effort, like health promotion and education for NPC, where smoking and drinking alcohol are still a risk factor for NPC. Furthermore, NPC management needs an intergrated and holistic evaluation with multidiscipline approach that involve public and private society.

Sequence variation from VEGF gene could affect VEGF production and activity that causing susceptibillity difference between individuals against various of disease like lung carcinoma (squamous cell carcinoma), but from this study in NPC, we could not prove it as a risk factor for NPC incidence in Makassar. And, new mutant variation in -457 $\mathrm{T} / \mathrm{C}$ that have not been reported before with $\mathrm{TC}, \mathrm{CC}$ genotypes and $\mathrm{T}$ allele could not be prove as a risk factor for NPC in Makassar and non-CC genotype VEGF gene $+405 \mathrm{C}$ / G, and non-TT genotype $-460 \mathrm{~T} / \mathrm{C}$ has not been prove too as risk factors of NPC in Makassar.

\section{Acknowledgement}

Sofia Mubarika Haryana, Moleculer Biology Department, Medical Faculty of Gajah Mada University, Jogjakarta Indonesia.

Irawan Yusuf and Budu (Moleculer Biology Department, Medical Faculty of Hasanuddin University, Makassar Indonesia)

Eigmen, Moleculer Biology Laboratorium Jakarta Indonesia

\section{References}

[1] Punagi AQ., Savitri E. Nasopharyngeal Carcinoma profile in the Teaching Hospital of the Faculty of Medicine, University of Hasanuddin period January 2004-June 2007. Makassar: Department of Otorhinolaryngology, Medical Faculty of Hasanuddin University. 2007.

[2] Punagi AQ. The Analysis of Vascular Endothelial Growth Factor Polymorphisms on Clinical and Histopathological Features of Nasopharyngalgeal Carcinoma. Bentham Open. 2013: 7; 10-13

[3] Punagi AQ. The Analysis of Vascular Endothelial Growth Factor Gene Polymorphisms on Nasopharyngeal Carcinoma in Makassar. Dissertation Post Graduate Program, Hasanuddin University. 2008

[4] Liebowitz D. Nasopharyngeal Carcinoma: The Epstein - Barr virus Association. Seminar in Oncology. 1994; 21(3): 376-380.

[5] Punagi AQ. Evaluation and nasopharyngeal In Endoscopic Biopsy in Clinical Cases Nasopharyngeal Carcinoma. Final works Medical Education Program Specialist-1 Otorhinolaryngology. Medical Faculty of Hasanuddin University. 1997.

[6] Chan ATC, Teo PML, Johnson PJ. Nasopharyngeal carcinoma. Review Article. Annals of Oncology. 2002; 13: 1007-1009.

[7] Kurniawan AN, Leong ASY. P53 protein over expression in nasopharyngeal carcinoma in Indonesian patients. Medical
Journal of Indonesia. Faculty of Medicine. Jakarta. University of Indonesia. 2000; 9 (3): 209-211.

[8] Rasyid A. Nasopharyngeal Carcinoma: Treatment radio diagnostic. Indonesian Medical Magazine. 2000; 50 (8): 400401 .

[9] Wolden SL. Cancer of Nasopharynx. In: Jatin P Shah et al (eds). Atlas Clinical Oncology Cancer of the Head and Neck. American Cancer Society. Hamilton London. BC Decker Inc. 2001; 146-148.

[10] Deng YF, Tian F, Lu YD, et al. Mutation and Abnormal Expression of the Fragile Histidine Triad Gene in Nasopharyngeal Carcinoma. Laryngoscope. 2001; 111: 15891590 .

[11] Chang KP, Hao SP, Lin SY, et al. A Lack of Association Between p53 Mutations and Recurrent Nasopharyngeal Carcinomas Refractory to Radiotherapy. Laryngoscope. 2002; 112: 2015-2018.

[12] Peters LJ, Rischin D, Corry J, et al. Cancer of the Nasopharynx. In: Head and Neck Cancer; A Multidisciplinary Approach. Louis B. Harrison et al (eds). $2^{\text {nd }}$ ed. Lippincott Williams \& Wilkins. Philadelphia. 2004; 529-536.

[13] Yoshizaki T, Wakisaka N, Pagano JS. Epstein Barr Virus Invasion and Metastasis. From: Epstein - Barr virus. Erle S. Robertson (ed). University of Pennsylvania Medical School, Philadelphia. Caister Academic Press. 2005; 171 - 189.

[14] Tsang NM, Chang KP, Lin SY, et al. Detection of Epstein-Barr Virus-Derived Latent Membrane Protein-1 Gene in Various Head and Neck Cancers: Is It Specific for Nasopharyngeal Carcinoma?. Laryngoscope. 2003; 113 (6): 1050-1053.

[15] Lee SJ, Lee SY, Jeon HS, et al. Vascular Endothelial Growth Factor Gene Polymorphisms and Risk of Primary Lung Cancer. Cancer Epidemiology, Biomarkers \& Prevention. 2005; 14 (3): 271-574.

[16] Steven A, Soden J, Brenchley PE, et al. Haplotype analysis of polymorphic human vascular endothelial growth factor gene promoter. Cancer Research 63. 2003; 15 (2): 812-816.

[17] Khabir A, et al. EBV latent membrane protein 1 abundance correlated with patient's age but not with metastatic behavior in North African nasopharyngeal carcinomas. Virology Journal. 2005; 2: 39.

[18] Lin JC, et al. Amino Acid Changes in Functional Domains of Laten Membrane Protein 1 of Epstem-Barr Virus in nasopharyngeal carcinoma of Southern China and Taiwan: Prevalence of and HLA2 - restricted epitome-loss variant. Journal of General Virology. 2004; 2033-2034.

[19] Perkasa MF. Accuracy brush biopsy endoscopic examination on suspected nasopharyngeal carcinoma. PPDS final work-I of Otorhinolaryngology, Medical Faculty of Hasanuddin University. 2005.

[20] Fransisca TBA. Accuracy of the results of endoscopic fine needle biopsy in suspected nasopharyngeal carcinoma. PPDS final work-I of Otorhinolaryngology, Medical Faculty of Hasanuddin University. 2004.

[21] Xie K, Wei D, Shi Q, et al. Constitutive and inducible expression and regulation of vascular endothelial growth factor. Cytokine \& Growth Factor Reviews 15, Elsevier Ltd. 2004. 297-324. 
[22] Felmeden DC, Blain AD, Lip GYH. Angiogenesis: basic path physiology and implications for disease. European Heart Journal. 2003; 24: 588-90.

[23] Mulyarjo. Diagnosis and treatment of nasopharyngeal carcinoma. The full text of continuing medical education III. Surabaya. 2002: 38-48.

[24] Soo R, Putti T, Tao Q, et al. Over expression of cyclooxygenase-2 in nasopharyngeal carcinoma and association with Epidermal Growth Factor receptor expression. Arch. Otolaryngology Head Neck Surgery. 2005; 02: 131: $147-52$.

[25] Liu ZE et al. Expression and Significance of VEGF-C and FLT-4 in Gastric Cancer, World J Gastroenterology. 2004; 1: 10 (3): 352-355.

[26] Claesson-Welsh L. Signal transduction by vascular endothelial growth factor receptors. Biochem Soc Trans. 2003; 31(Pt1): $20-4$.
[27] Rosen LS. Clinical experience with angiogenesis signaling inhibitors: focus on vascular endothelial growth factor (VEGF) blocker. Cancer Control. 2002; 9 (2 suppl): 36-44.

[28] Murono $\mathrm{S}$, Inoue $\mathrm{H}$, Tanabe $\mathrm{T}$, et al. Induction of cyclooxygenase-2 Epstein-Barr virus latent membrane protein 1 is involved in vascular endothelial growth factor production in nasopharyngeal carcinoma cells. Proceedings of the National Academy of Sciences of the United States of America. 2001; 10: 1073-1074.

[29] Prats AC, Prats H. Translational control of gene expression: Role of IRESs and consequences for cell transformation and angiogenesis. Prog Nucl Acid Res Mol Biol. 2002; 72: 367413. 